\title{
STOPOVER ECOLOGY OF SOME PASSERINES AT ANKARA (CENTRAL TURKEY)
}

\author{
Özge Keşaplı Can and Cemal Can Bilgin
}

\begin{abstract}
Keşaplı Can Ö., Can Bilgin C. 2005. Stopover ecology of some passerines at Ankara (Central Turkey). Ring 27, 2: 127-136.

In autumn 2002 we studied little known passerine migration at a woodland patch within the Middle East Technical University (METU) campus in Ankara (Turkey). A total of 954 individuals of 35 passerine species were mist-netted, ringed, measured, weighed and fat-scored (after Busse 2000). Blackcap (Sylvia atricapilla) and Willow Warbler (Phylloscopus trochilus) were the two most common species, with 308 and 145 individuals caught, respectively. Both are passage migrants at METU, recorded from mid-August to late October, representing several waves.

Only $11.5 \%$ of Blackcaps had the fat score of $T_{6}$ and above, and among 20 retraps only 2 gained fat significantly. All the other retraps lost fat, stayed the same, or increased 1-2 scores at most. In contrast, Willow Warblers, as true trans-Saharan migrants, had the much higher proportion (46\%) of individuals with fat scores of $T_{6}$ and above. Most retrapped individuals gained fat, some with already high levels stayed the same, while none lost fat. We interpret these data in terms of known migratory ranges, diet types and habitat patch quality.

Although daily catches were low, a diverse range of species used METU as a stopover site. Fat deposition rates (of up to $50 \%$ of body weight within a week) suggest that the study site provided a high quality stopover habitat for most migrants. In Central Turkey, such suitable habitats with trees or tall shrubs are scarce, and therefore, crucial for migrants.
\end{abstract}

Ö. Keşaplı Can, Turkish Bird Research Society (KAD), Atatürk Bulvarı, 143/38, Bakanlıklar, Ankara, Turkey; C. Can Bilgin, Turkish Bird Research Society (KAD), Atatürk Bulvarı, 143/38, Bakanlıklar, Ankara, Turkey; Department of Biology, Middle East Technical University, Ankara 06531, Turkey

Key words: passerine migration, autumn, fat deposition, stopover ecology, Sylvia atricapilla, Phylloscopus trochilus

\section{INTRODUCTION}

Birds need extra energy for their migratory journey. Being an optimal flight fuel, excessive amounts of fat are stored by birds and other migratory animals before migration. It is known that short or medium distance passerine migrants have fat loads 
of $10-25 \%$ and long distance migrants regularly have fat loads in the range $30-50 \%$ of live body mass at departure for migration (Berthold 1993).

Migrants need regular refueling. It is known that the typical migratory journey of a passerine is composed of only several hundred kilometers of flight and then 1 to 3 days of rest and refueling (Winker et al. 1992a, b).

Although Turkey is a very important land bridge for many migratory birds between Europe and Africa, there haven't been any systematic studies carried out on bird migration till the start of National Ringing Scheme (NRS). During the $\mathrm{XX}^{\text {th }}$ century more than 17000 birds of 166 bird species were ringed in Turkey and more than 750 birds, ringed in 43 different foreign countries, were reported from Turkey during episodic ringing expeditions conducted by visiting foreign ringers, which shows the importance of Turkey for bird migration (Tavares 2002). In March 2002, Turkish Bird Research Society (KAD) in collaboration with General Directorate of National Parks and Wildlife (Ministry of Forestry) and METU Biology Department launched the NRS. More than 100000 birds of over 100 species have been ringed at 6 stations so far (Keşaplı Can and Keşaplı Didrickson 2003, 2004).

It is shown by Busse (2001) that the knowledge of birds that migrate by eastern flyway, where Turkey is also located, is lacking in particular. It is thought that Central and Eastern Europe is larger and richer in passerine populations than the rest of Europe and actually more European passerines migrate over the south-eastern flyway than the south-western one. It is impossible to understand the passerine migration system over Europe without detailed research on bird migration through the south-eastern flyway. Therefore migration studies in Turkey are of utmost importance.

This research has been the first attempt in Turkey to study passerine migration systematically and it has been aimed at investigation of the importance of METU as a stopover site for the most common migrants.

\section{STUDY AREA AND METHODS}

This study was carried out in METU campus field, Ankara (north-western part of Central Anatolia) - see Figure 1. The METU campus field is mainly dominated by steppe vegetation although parts of the land have been afforested with conifers.

The habitat of Yalıncak (39 $52^{\prime} \mathrm{N}, 32^{\circ} 47^{\prime} \mathrm{E}$, alt. $1063 \mathrm{~m}$ a.s.l.), which is an old nursery, can be described as a willow grove surrounded by shrubland and open land. In the middle of the study site there is a small stream along which tall willows (Salix spp.) and Black Poplar (Populus nigra) trees grow. Under the trees, there are dense shrubs of mainly Dog Rose (Rosa canina) and tall herbs. Further away from the stream, there is open land covered by Dock (Rumex patientia), various grasses, scattered tall shrubs of Dog Rose, Wild Pear (Pyrus eleagrifolia) and Common Hawthorn (Crataegus monogyna). There is also a small grove formed by Wild Almonds (Prunus spp.) and Common Hawthorns. 


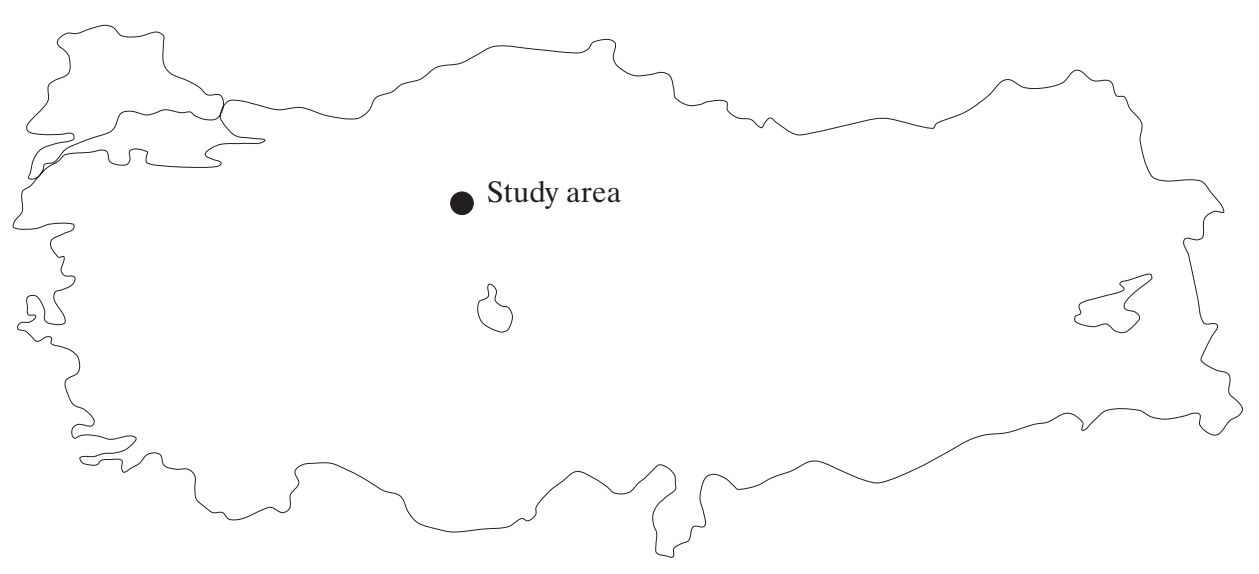

Fig. 1. Localization of the study area in Turkey

The study was carried out continuously from 18 August to 29 October 2002. Birds were captured with 6, 7 and $12 \mathrm{~m}$ long nylon mist-nets. Total net length was $123 \mathrm{~m}$ and the nets were open all day long following SEEN methodology (Busse 2000). All individuals were ringed, weighed and the wing formula (feather tips distances method), wing length (maximum chord), tail length (to the back method after Busse 1983, 1990) were measured. Besides, fat score was estimated visually with the help of 3 level (belly, furculum and pectoral muscles) key system according to 9 (0-8) graded scale (after Busse 1983 and Kaiser 1993, combined as in Busse 2000).

Results were analysed mainly by graphing the daily totals against time (days) for all species, and also separately for Blackcap (Sylvia atricapilla), Willow Warbler (Phylloscopus trochilus), Chiffchaff (P. collybita) and Robin (Erithacus rubecula). Data smoothing was carried out as three times repeated 5-day running average with the formula:

where:

$$
D_{x}=0.06 d_{x-2}+0.24 d_{x-1}+0.40 d_{x}+0.24 d_{x+1}+0.06 d_{x+2}
$$

$d_{x}$ - number of birds ringed on the $x$-th day (Busse 2000).

Fat scores were analysed by graphing against weights, by averaging over pentades (five-day periods starting on 1 January - Berthold 1973, Busse 2000), and for retraps by connecting values recorded from each retrapped individuals through time.

\section{RESULTS}

In autumn 2002, 954 individuals of 35 passerine species were caught and ringed, 116 individuals of 14 species were retrapped and 5 individuals of the Nightingale (Luscinia megarhynchos) ringed in previous seasons were controlled.

The Blackcap was the dominant species with the 308 individuals (33\%), followed by Willow Warbler with 145 individuals, Chiffchaff with 98 individuals, Robin with 79 individuals, Redstart (Phoenicurus phoenicurus) with 42 individuals and Spotted Flycatcher (Muscicapa striata) with 36 individuals (Table 1). Long-distance 
migrants constituted $74.3 \%$ of all birds and the rest were either short-distance migrants or winter visitors.

Table 1

Number of birds ringed

\begin{tabular}{|c|c|}
\hline & $N$ \\
\hline Sylvia atricapilla & 308 \\
\hline Phylloscopus trochilus & 145 \\
\hline Phylloscopus collybita & 98 \\
\hline Erithacus rubecula & 79 \\
\hline Phoenicurus phoenicurus & 42 \\
\hline Muscicapa striata & 36 \\
\hline Ficedula parva & 28 \\
\hline Fringilla coelebs & 28 \\
\hline Sylvia borin & 22 \\
\hline Sylvia curruca & 20 \\
\hline Acrocephalus palustris & 19 \\
\hline Carduelis spinus & 19 \\
\hline Anthus trivialis & 16 \\
\hline Sylvia communis & 13 \\
\hline Ficedula albicollis & 12 \\
\hline Turdus philomelos & 11 \\
\hline Phylloscopus sibilatrix & 9 \\
\hline Lanius collurio & 8 \\
\hline Lanius nubicus & 8 \\
\hline Luscinia luscinia & 7 \\
\hline Luscinia megarhynchos & 6 \\
\hline Prunella modularis & 4 \\
\hline Hippolais icterina & 2 \\
\hline Regulus ignicapillus & 2 \\
\hline Sylvia melanocephala & 2 \\
\hline Hippolais pallida & 1 \\
\hline Emberiza hortulana & 1 \\
\hline Carpodacus erythrinus & 1 \\
\hline Oriolus oriolus & 1 \\
\hline Phylloscopus bonelli & 1 \\
\hline Hippolais olivetorum & 1 \\
\hline Acrocephalus scirpaceus & 1 \\
\hline Saxicola rubetra & 1 \\
\hline Emberiza melanocephala & 1 \\
\hline Serinus serinus & 1 \\
\hline Total & 954 \\
\hline
\end{tabular}

A migrants flow through the area was not stable and birds passed the place in several waves (Fig. 2). The course of seasonal migration dynamics was influenced by waves of the most common migrants (Fig. 3), but the first October wave was caused by coincidence of waves of all four commonest species. The highest daily catch was on 5 September with 34 individuals, the second - on 10 October with 30 individuals and the third - on 4 September with 28 individuals. 


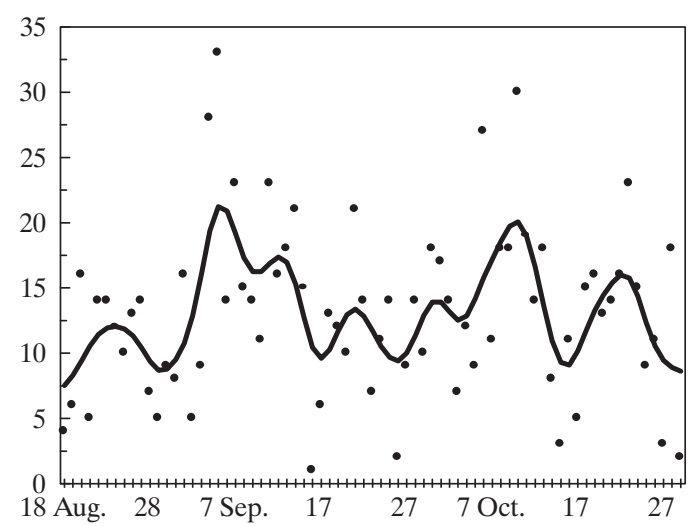

Fig. 2. Total seasonal number dynamics in 2002. Dots - daily catches, line - moving average
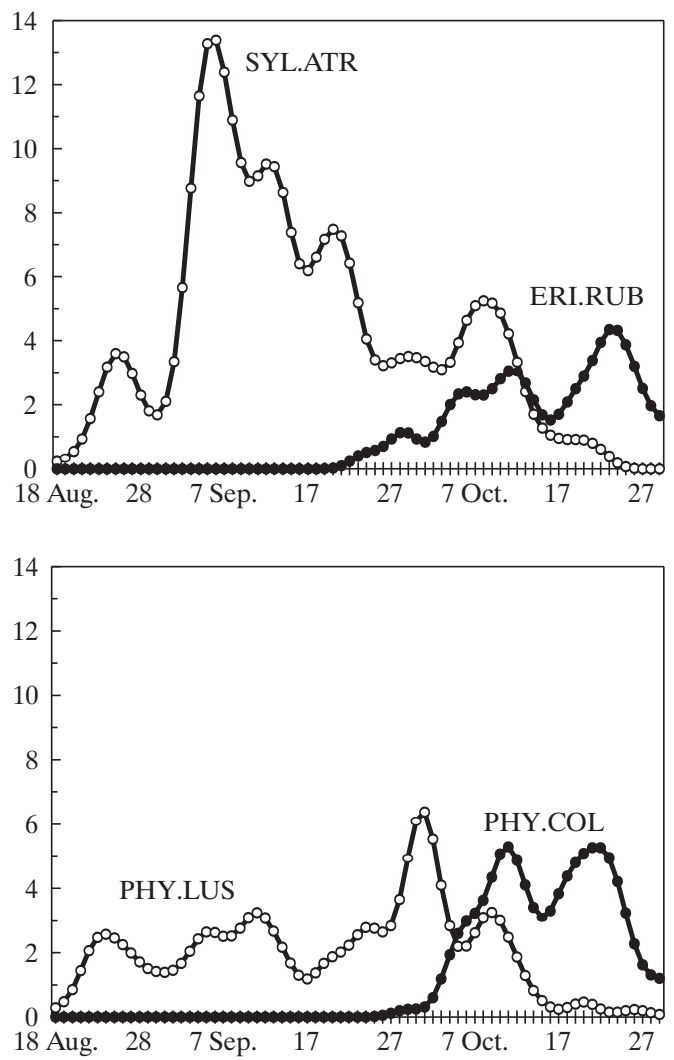

Fig. 3. Seasonal number dynamics for the Blackcap (SYL.ATR), the Robin (ERI.RUB), the Willow Warbler (PHY.LUS) and the Chiffchaff (PHY.COL) - smoothed by moving average

The Blackcap and the Willow Warbler do not breed in METU and they are passage migrants only. Migration of Blackcaps occurred from 20 August to 22 October, so it covered practically all period of the study. The highest daily catches were on 4 , 5 and 7 September. Later migration of this species was less intensive than at the be- 
ginning. Migration of Willow Warblers covered similar terms, with the highest catch on 1 October. Willow Warblers' migration was less differentiated than that of Blackcaps (Fig. 3).

Studying the stopover ecology of migrating birds one should look for relations between fat score and body mass of migrants as this allows to estimate changes in fat load in a course of the stopover at a defined place. Figure 4 illustrates these relations for the Blackcap and the Willow Warbler. In the Blackcap between scores $T_{0}$ and $T_{5}$ the fat load grows constantly and then, scores $T_{6}$ and $T_{7}$ mean much higher changes in the body mass (and fat) than at lower scores. The quasi-linear growth of the fat load at scores $T_{0}$ to $T_{5}$ was noted in Blackcaps caught at the Baltic coast (Ścisłowska and Busse 2005), but there the average body mass for individuals scored as $T_{5}$ was 4-5 g (depending on sex) higher than for these scored as $T_{0}$ (in our case this difference was only $2.62 \mathrm{~g})$. It is interesting that two next fat scores ( $T_{6}$ and $T_{7}$, not observed at the Baltic coast) mean a gain of as much as $6.22 \mathrm{~g}$ of the body mass. In contrary, in the Willow Warbler the body mass differences between birds scored as $T_{0}$ and $T_{5}$ are similar (2.37 g in Poland and $2.53 \mathrm{~g}$ at our place). The only difference in the fat load pattern was the absence of individuals with $T_{6}-T_{7}$ in Poland
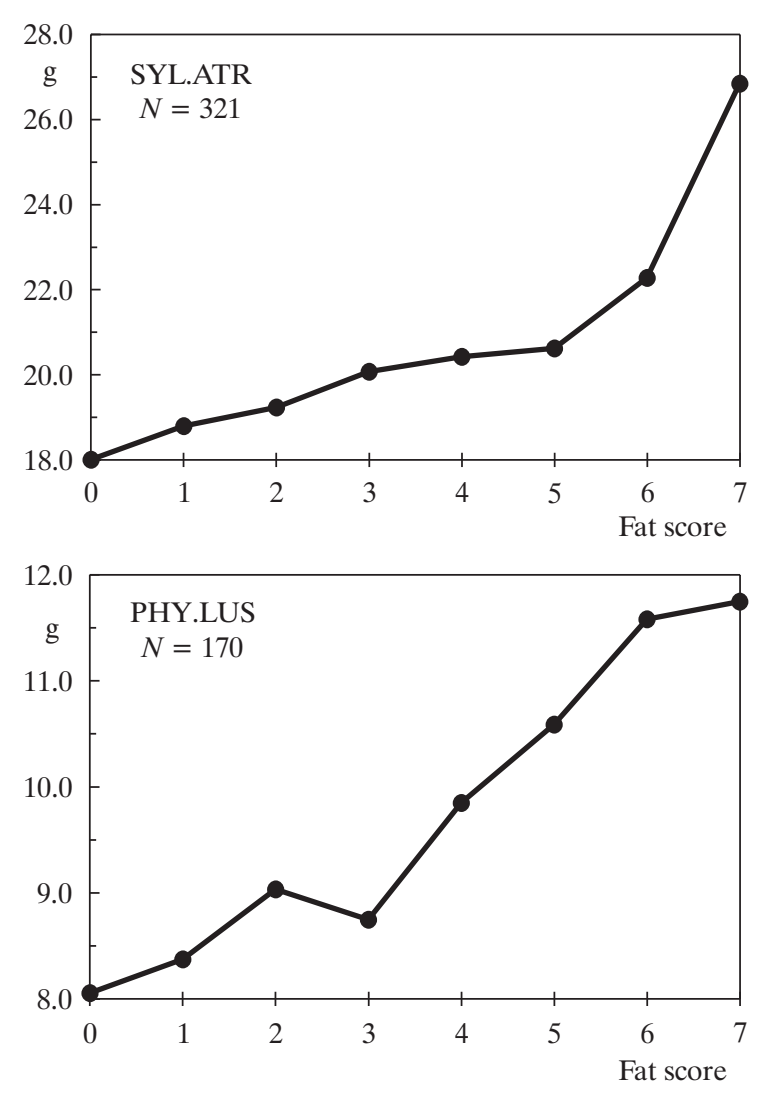

Fig. 4. Relations between fat score and body mass for the Blackcap (SYL.ATR) and the Willow Warbler (PHY.LUS) 
while at METU we had as much as $58 \%$ of such birds (on average they gained next $1.16 \mathrm{~g}$ of weight).

Since significant barriers like the Mediterranean and the Sahara are still some considerable distance away, and since it is costly to accumulate excess levels of fat, it is expected that Blackcaps on average should not deposit high levels of fat. Moreover, some populations of this species do not cross the Sahara and may even winter in southern Turkey. Individuals from such populations should have low to medium levels of fat compared to trans-Saharan migrants. This is indeed reflected in the low proportion (11.5\%) of individuals with fat scores of $T_{6}$ and above. The same is visible in Figure 5 - low level of the fat load and not too big changes over the course of the season. Average fat scores of caught individuals by pentades show a gradual increase from below 1.5 up to 2.5 within the first 20 days (late August to midSeptember), followed by fluctations around the latter value, and finally a steep drop down to the average fat score of about 1.0 within the final week (late October). Statistically, only the difference between the consecutive pentades 50 and 51 is significant. The rest of the pattern is not so much differentiated and some coincidences between changes in the fat score level changes and migration waves should be studied in the future to check whether they mean interpopulational differences.

In contrary to Blackcaps, Willow Warblers are all true trans-Saharan migrants with no populations wintering north of the Sahara. Therefore, one should predict higher average fat score levels compared to those of the Blackcap. Figure 5 con-
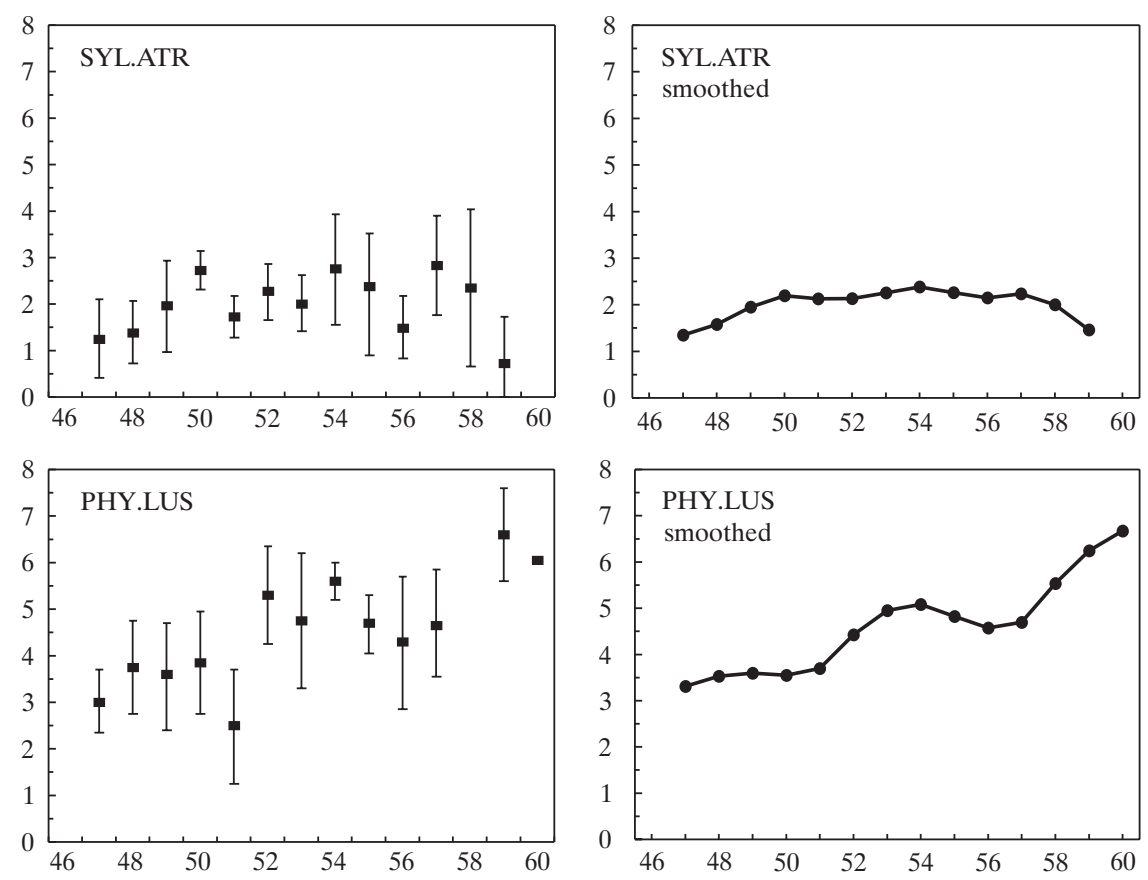

Fig. 5. Fat scores for pentades for the Blackcap (SYL.ATR) and the Willow Warbler (PHY.LUS). Left panels - average $\pm 1.96 \mathrm{SE}$, right panels - smoothed by moving average 

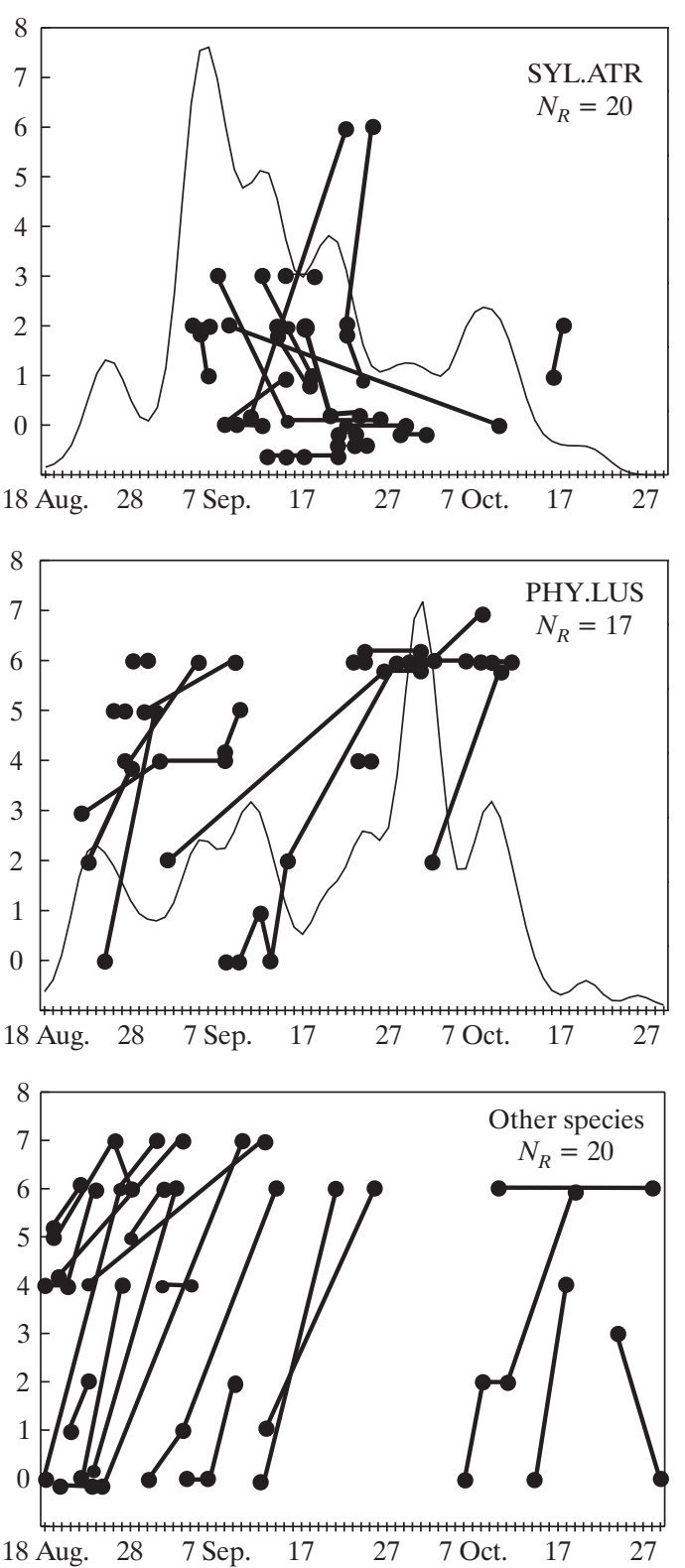

Fig. 6. Changes of the fat score in retraps for the Blackcap (SYL.ATR), the Willow Warbler (PHY.LUS) and other bird species. Thin line - smotthed catch dynamics.

firms this. In this species the proportion of individuals with fat scores $T_{6}$ and above is high $(46 \%)$.

Average fat scores of caught individuals by pentades show a significant jump from the average value of about 3.5 during the first month (late August to midSeptember) to the average value of about 5.0 in the latter part. These periods correspond to the first two and the latter two waves, respectively, as shown in Figure 2. 
Again, since the origin of those waves (i.e. populations) are not known, further elaboration of this finding is not possible.

Beside the observed fat level of migrants, the dynamics of fat accumulation is crutial for evaluation of a certain locality as a stopover for migrating birds. Figure 6 gives an idea about fat load changes during the stopover at METU. There are visible clear differences between the pattern of retrapping / fat load changes between Blackcaps and other species.

Out of 20 Blackcap retraps, only two of them gained considerable amounts of fat: from $T_{0}$ to $T_{6}$ in 3 days and from $T_{2}$ to $T_{6}$ in 11 days - which means $5.75 \mathrm{~g}$ $(0.53 \mathrm{~g} /$ day $)$. All other retraps lost fat, increased only $1-2$ scores or stayed at the same level. The former might belong to long distance migrant populations although there is no data to support this. Another explanation is that such birds might occupy and defend higher quality habitat patches compared to others (Alerstam 1990). Blackcaps consume large amounts of fruit (mainly berries) for fat deposition during migration (Snow and Perrins 1998). There is only very localised source of berry shrubs - Wild Jasmine (Jasminum fruticans) - at Yalıncak, supporting the second explanation.

It can be seen in Figure 6 that Willow Warblers as long distance migrants gained fat (e.g. from $T_{0}$ to $T_{\theta} T_{2}-T_{>} T_{2}-T_{6}$ ). None of them lost fat, some stayed at the same level (but they already had high level of fat). The retrapping/fat load pattern is very different here from that for Blackcaps. This is clearly a problem for further studies.

The numbers of individuals retrapped of other species are too low to permit an analysis similar to that performed for Blackcap and Willow Warbler. However, it seems that the pattern follows that of the Willow Warbler rather than of the Blackcap. Some examples of the fattening rates are given in Table 2 .

Table 2

Fattening rates of some migrants retrapped at METU station

\begin{tabular}{|c|c|c|c|c|}
\hline & Date & Fat score & Body mass (g) & Fattening rate (g/day) \\
\hline Sylvia communis & $\begin{array}{l}23 \text { Aug. } \\
1 \text { Sep. }\end{array}$ & $\begin{array}{l}0 \\
6\end{array}$ & $\begin{array}{l}12.50 \\
19.50\end{array}$ & 0.78 \\
\hline Luscinia luscinia & $\begin{array}{l}20 \text { Aug. } \\
23 \text { Aug. } \\
24 \text { Aug. } \\
10 \text { Sep. }\end{array}$ & $\begin{array}{l}0 \\
0 \\
0 \\
7\end{array}$ & $\begin{array}{l}22.50 \\
22.25 \\
23.25 \\
32.50 \\
\end{array}$ & 0.57 \\
\hline Acrocephalus palustris & $\begin{array}{l}18 \text { Aug. } \\
27 \text { Aug. } \\
31 \text { Aug. }\end{array}$ & $\begin{array}{l}0 \\
6 \\
7\end{array}$ & $\begin{array}{l}11.75 \\
14.50 \\
17.50\end{array}$ & 0.44 \\
\hline Muscicapa striata & $\begin{array}{c}30 \text { Aug. } \\
3 \text { Sep. } \\
14 \text { Sep. }\end{array}$ & $\begin{array}{l}0 \\
1 \\
6 \\
\end{array}$ & $\begin{array}{l}15.00 \\
16.00 \\
21.50\end{array}$ & 0.43 \\
\hline Luscinia megarhynchos & $\begin{array}{l}23 \text { Aug. } \\
13 \text { Sep. }\end{array}$ & $\begin{array}{l}4 \\
7\end{array}$ & $\begin{array}{l}23.75 \\
31.00\end{array}$ & 0.35 \\
\hline
\end{tabular}




\section{CONCLUSION}

In Central Anatolia, which is dominated by steppe habitats and agricultural fields, suitable habitats as stopover sites for long distance migrants are scarce. Therefore, even small patches with trees or tall shrubs are crucial to a wide variety of migrant passerines. The diverse number of such species ringed at METU shows that these habitats are indeed utilized by a variety of migrants.

As it was expected, birds migrate over METU in a series of consecutive, sometimes overlapping, waves. Such waves probably represent populations with different geographical origins and/or migratory strategies. Long-term standardised ringing research is required in order to understand the real nature of these waves and migration strategies of different species and populations. Analysis of fat deposition rates showed that at least Yalıncak serves as a good stopover site for many species to replenish fat reserves. Long-distance migrants, with a long way ahead, had higher average fat scores compared to those wintering in nearby regions.

\section{REFERENCES}

Alerstam T. 1990. Bird Migration. Cambridge Univ. Press, Cambridge.

Berthold P. 1973. Proposals for the Standardization of the Presentation of data of annual Events, especially of Migration data. Auspicium 5, Suppl.: 49-59.

Berthold P. 1993. Bird Migration: A general survey. Oxford Univ. Press, Oxford.

Busse 1983. Biometrical standards in the Operation Baltic work. Ring 116: 125-138.

Busse 1990. Studies of long term population dynamics based on ringing data. Ring 13: 221-234.

Busse P. 2000. Bird Station Manual. SE European Bird Migration Network, Univ. of Gdańsk, Gdańsk.

Busse P. 2001. European passerine migration system - what is known and what is lacking. Ring 23, 1-2: 3-36.

Kaiser A. 1993. A new multi-category classification of subcutaneous fat deposits of songbirds. J. Field Ornithol. 64, 2: 246-255.

Keşaplı Can Ö., Keşaplı Didrickson Ö. 2003. [Ringing report of 2002.] Kuş Araştırmaları Derneği (KAD), Ankara. (In Turkish).

Keşaplı Can Ö., Keşaplı Didrickson Ö. 2004. [Ringing Report of 2003.] Kuş Araştırmaları Derneği (KAD), Ankara. (In Turkish).

Snow D.W., Perrins C.M. 1998. The Birds of the Western Palearctic. Vol. 2: Passerines. Oxford Univ. Press, Oxford.

Ścisłowska M., Busse P. 2005. Fat reserves and body mass in some passerines migrating in autumn through the southern Baltic coast. Ring 27, 1: 3-60.

Winker K., Warner D.W., Weisbrod A.R. 1992a. Migration of woodland birds at a fragmented inland stopover site. Wilson Bull. 104: 580-598.

Winker K., Warner D.W., Weisbrod A.R. 1992b. Daily mass gain among woodland migrants at an inland stopover site. Auk 109: 853-862.

Tavares J. 2002. [Bird ringing studies in Turkey in 20th century.] İbibik 2: 19-20. (In Turkish). 